\title{
Development of Interactive World History Babon Book Application Based on Big Data as a Digital Learning Source for History Education Students in MBKM Curriculum
}

\author{
Abd. Haris Nasution ${ }^{1}$ Flores Tanjung ${ }^{1}$ Feri Andi Syuhada ${ }^{1}$ \\ ${ }^{1}$ Universitas Negeri Medan, Jl. Willem Iskandar \\ *Corresponding author. Email: abdharisnasution@unimed.ac.id,flores_tanjung@yahoo.co.id, \\ feriandisyuhada@unimed.ac.id
}

\begin{abstract}
This research is motivated by the need for an Interactive World History Babon Book Application as a big data-based digital learning resource that can be accessed by students of the Department of History Education from all over the country. This application is needed to answer the challenges of Education in the Industrial Revolution Era 4.0 and the Independent Learning Curriculum of the Independent Campus. In learning world history/spatial history, lecturers and students usually only use printed teaching resources whose content is not relevant to the CPL-CPMK Department of History Education FIS UNIMED. This is because the currently available baboon printed books only contain limited material about the history of human civilization with a limit of years in the 20th century, while in the 21 st century there have been drastic changes in culture and civilization experienced by humans, coupled with the outbreak of a pandemic that has plagued humans. also change the pattern of human life habits. Then the use of the interactive world history baboon book application will make it easier for students of the History Education Department to explore other learning resources in the form of multimedia such as audio, video, animation, photos, graphics, etc. In addition, the application will give students access to historical archives from the KITLV, ANRI, National Library sites, to the latest scientific articles through the national.international Journal links that will be available on the application. Therefore, research on the development of the big data-based Interactive World History Babon Book Application that is connected to it is important to do. As for the formulation of the problem, among others: 1) How to develop an interactive World History Babon book application based on Big Data as a digital learning resource for History Education Students in the Merdeka Belajar Kampus Merdeka Curriculum? 2) How is the Effectiveness of the Big Data-based interactive World History Babon book application as a digit.
\end{abstract}

Keywords: Development, Babon book, World History.

\section{INTRODUCTION}

The Independent Learning Campus Independent Curriculum is one of the strategic policies/programs of the Minister of Education and Culture in improving the quality of Indonesian human resources through higher education in facing global challenges. Through Regulation of the minister of education and culture No. 3 of 2020 it is explained that every university is obliged to facilitate students in strengthening competencies by providing opportunities to take learning outside the study program at the same university and/or taking learning in the same study program at a different university. In response to this program, since the 2019/2020 FY,
Medan State University as an A-accredited PT (SK BANPT No.2988/SK/BAN-PT/Akred/PT/XII/2016) has also opened up the widest opportunities for students to carry out This policy is carried out through several student exchange programs such as Permata Sakti, Permata Sari, Internships, etc. The Ministry of Education program also provides a stimulus for the State University of Medan to optimize distance learning to accommodate the needs of MBKM in conducting online lectures using learning platforms such as SIPDA, GAFE (Google Application For Education), Zoom, etc. These platforms are certainly very much needed by lecturers and students in distance lecture activities at MBKM, especially during the pandemic. 
To optimize classical, blended, and distance learning at MBKM, in addition to use the learning platform provided by the State University of Medan, every lecturer certainly needs to develop interactive digital learning materials as an alternative to printed teaching materials. Interactive digital teaching materials are learning resources that contain complete teaching materials enriched with multimedia facilities such as audio, video, animation, photos, graphics, journal web links, etc. These teaching materials allow students from all over the country to be able to obtain relevant learning resource applications with smartphones based on Android and iOS via Google Play and the App Store, so that classical, blended, long-distance or full-online history learning can run more effectively, flexibly and efficiently. efficient. Quantitatively, these interactive digital teaching materials are rare in the Faculty of Social Sciences, State University of Medan, especially in the Department of History Education.

The Department of History Education is one of the Aaccredited departments (SK BAN-PT No. 1161/SK.BAN-PT/Akred/S/VII/2016) within the FIS UNIMED environment that implements the MBKM curriculum in accordance with the Rector's Regulation No. 0362/UN33/PRT/2020 concerning Freedom of Learning. The MBKM curriculum certainly requires every Lecturer in the Department of History Education FIS UNIMED to be able to develop PBM activities both offline, blended learning, and fully online as an adaptation of the Industrial Revolution 4.0 in the world of education. Especially during the implementation of distance learning (PBJJ) as a result of the Covid-19 pandemic in the MBKM era, fully online learning is a mandatory solution in the implementation of PBM activities. In addition, to maximize the Merdeka Learning lecture program that allows History Education Department students from other universities to come to join and attend lectures at the Department of History Education, Faculty of Social Science UNIMED, we need an application of interactive digital teaching materials that can be used effectively, flexibly and relevantly to the learning outcomes. Department of History Education Faculty of Social science UNIMED. That is the application of teaching materials that can be accessed easily using smartphones by all History Education students throughout the country who take lectures both offline, blended learning, and fully online at the Department of History Education FIS UNIMED.

The big obstacle faced in lectures at the Department of History Education FIS UNIMED in the RI 4.0 era and the MBKM curriculum, one of which was the absence of digital baboon books that were up to date and relevant to the CPL-CPMK Department of History Education FIS UNIMED. Especially for the group of world history courses or so-called spatial histories such as American History, European History, African History, Asian History, and other spatial history courses. The world history baboon book is available in the market and currently is a printed/non-digital baboon book by Arnold Toynbee which was reissued in 2017 which is a reproduction of the baboon book that was published in 1939 ago. (Ponting, 2007). This means that the content of the material contained in the printed baboon book only reaches 20th-century historical studies (not up to date), and even then with the relatively limited content of spatial history material and is not in accordance with CPL and CPMK on the MBKM Curriculum that has been formulated by the Team Department of History Education so that these teaching materials cannot meet the needs of Lecturers and Students for world history teaching materials that are valid and relevant to the CPLCPMK.

Therefore, like the previous description, an interactive digital Baboon Book or World History Ledger application is needed to help optimize the competence of students of the History Education Department towards the materials in the World/Spatial History course class, so that each CPL-CPMK can maximally be achieved. In this case, research on the development of digital teaching materials in the form of an interactive World History Ledger application can be a novelty and something very important to do to answer the challenges of Higher Education in the RI 4.0 Era and Independent Learning to support Medan State University to become The WorldClass University in the future.

\section{METHOD}

The method used in this research is the research and development method. A development research method is a method used to produce certain products, and test the effectiveness of these products (Gooch, 2012:407). Research and Development is a process or steps to develop a product or improve existing products, which can be accounted for (Borg and Gall, 2003).

\section{RESULT AND DISCUSSION}

The big data-based world history baboon book application developed by the author was validated by two experts, namely: material experts and media experts. Validation is carried out on the content or material (concepts and facts) and teaching (concern for the formation of attitudes and skills) by material experts. Presentation (systematics and image illustrations) by media experts, as well as students of History Education Class C Reg 2019 as a product test of the big data-based world history Baboon Book Application.

\subsection{Material Expert Validation}

Material validation includes material coverage, material systematics, and presentation. The results obtained from the first stage of validation can be seen in Table 1. 
Table 1. Material Expert Validation Results

\begin{tabular}{clcccc}
\hline No & \multicolumn{1}{c}{ Item } & Score & Max Score & Presentage & Criteria \\
\hline 1 & Content Eligibility & 16 & 20 & 80 & Eligible \\
2 & Serving Eligibility & 4 & 5 & 80 & Eligible \\
3 & Language & 3 & 5 & 60 & Enough/Nearly \\
4 & World history & 4 & 5 & 80 & Eligible \\
& material approach & & & \\
\hline Total & & \multicolumn{5}{c}{$77,1 \%$} \\
\hline Max Score & & Eligible \\
\hline Presentage &
\end{tabular}

Table 2. Media Expert Validation Results

\begin{tabular}{llcccc}
\hline No & Indicators & Score & Max. Score & Presentage & Criteria \\
\hline 1 & Size & 25 & 30 & 83 & Very Eligible \\
2 & Layout Design & 48 & 50 & 96 & Very Eligible \\
3 & Content Design & 38 & 40 & 95 & Very Eligible \\
\hline Total & \multicolumn{5}{c}{111} \\
Max. Score & \multicolumn{5}{c}{ Very Eligible }
\end{tabular}

The results of the material expert assessment in Table 1 show that the validation of the material expert is $77.1 \%$ with proper criteria. Aspects of content quality with an average percentage of $80 \%$ with appropriate criteria, aspects of presentation feasibility get a percentage of $80 \%$ with appropriate criteria, in the language aspect a percentage of $60 \%$ is obtained with fairly decent criteria, and aspects of the assessment approach in the american history course get a percentage by $80 \%$ with proper criteria.

\subsection{Media Expert Validation}

The media expert validation aims to test the big databased world history Baboon Book Application using the Flipbook application. The results of the media validation data can be seen in Table 2.

The total value of the media expert validation on the teaching material size indicator is 25 with a maximum score of 30 so that the percentage value is $83 \%$. The number of validation values on the layout design indicator is 48 with a maximum score of 50 so that a percentage of $96 \%$ is obtained. While the number of validation values in the content design is 38 with a maximum score of 40 , so the percentage value is $95 \%$. The results of the media expert's design validation were declared very feasible. The total media validation score is 111 with a maximum score of 120 , so the overall percentage of media experts is $92.5 \%$ with very decent criteria.

\subsection{Product Trial}

Implementation is carried out after being declared feasible by material and media expert validators. Furthermore, the implementation will be tested on students of one of the 2019 Regular C classes in the American History Course at the UNIMED History Education Department, totaling 34 people. After students see and use the big data-based world history baboon book application, they will then give an assessment of the product by filling out a response questionnaire following the existing statements.

Teaching material products that have received proper recommendations from material experts and media experts have met the requirements to be tested in the field. The average score obtained in the limited field test, wider field test, and operational test were 4.19, 4.26, and 4.14 , respectively, with good, very good, and good categories. The results of the analysis of student assessment scores for each criterion and indicator are described in the table below. 
Table 3. Analysis of Student Assessment Results in Field Tests per-Indicator

\begin{tabular}{llccccc}
\hline Criteria & \multicolumn{1}{c}{ Indicator } & Item & $\begin{array}{c}\text { Item } \\
\text { Number }\end{array}$ & Small/Limited & Larger & Operational \\
& & & 1,2 & 4,33 & 4,08 & 3,97 \\
Material & Material Interest & 2 & 3 & 4,00 & 4,17 & 4,16 \\
delivery & Benefits for & 1 & & & & \\
& students & & & 3,67 & 4,50 & 4,21 \\
& Contextualiity & 1 & 4 & 5,00 & 4,17 & 4,26 \\
& Material & 1 & 5 & & & \\
& summary & & & 4,33 & 4,00 & 4,11 \\
\hline Media & language & 1 & 6 & 4,16 & 4,25 & 3,94 \\
delivery & Size & 2 & 7,8 & 4,33 & 4,67 & 4,16 \\
& Convenience & 1 & 9 & 4,33 & 4,17 & 4,37 \\
& Color & 1 & 10 & 3,67 & 4,33 & 4,32 \\
& Letter & 1 & 11 & 3,67 & 4,50 & 4,11 \\
& Illustration & 1 & 12 & 3,67 & 4,00 & 4,16 \\
& Material content & 2 & 13,14 & 4,44 & 4,22 & 4,14 \\
& Media use & 3 & $15,16,17$ & 4,33 & 4,83 & 4,26 \\
& Technical & 1 & 18 & & & $\mathbf{4 , 2 6}$ \\
\hline
\end{tabular}

The results of student assessments in terms of material presentation (student assessment points numbered 1-6) in the limited test obtained an average score of 4.28 , meaning that the presentation of material in the developed teaching materials was very good. The indicators assessed include the attractiveness of teaching materials, benefits for students, contextual materials, summary of materials and use of language with a score of 4.33 each; $4.00 ; 3.67 ; 5.00$; and 4.33. Meanwhile, in terms of presentation of teaching materials (student assessment points number 7-18) an average score of 4.14 means that the teaching materials developed are good. Assessment indicators include shape and size, ease of use, choice of color, use of letters, illustration images, content of teaching materials, usefulness of teaching materials, and technical quality with a score of 4.16 each; $4.33 ; 4.33 ; 3.67 ; 3.67 ; 3.67 ; 4.44$; and 4.33 .

The results of student assessments in terms of material presentation (student assessment points numbered 1-6) in the broad test obtained an average score of 4.17 , meaning that the teaching materials developed were good. The indicators assessed include the attractiveness of teaching materials, benefits for students, contextual materials, summary of materials and use of language with a score of 4.08 each; $4.17 ; 4.50 ; 4.17$; and 4.00. Meanwhile, in terms of presentation of teaching materials (student assessment points number 7-18) obtaining a score of 4.31 means that the product of teaching materials developed has been very good. The assessment indicators include shape and size, ease of use, choice of colors, use of letters, illustration images, content of materials, usability of teaching materials, and technical quality with a score of 4.25 each; $4.67 ; 4.17$; $4.33 ; 4.50 ; 4.00 ; 4.22$; and 4.83 .

The results of student assessments in terms of material presentation (items number 1-6) in the operational test obtained an average score of 4.11, meaning that the teaching materials developed were good. The indicators assessed include the attractiveness of teaching materials, benefits for students, contextual materials, summary of materials and use of language with a score of 3.97 each; 4.16; 4.21; 4.26; and 4.11. Meanwhile, in terms of presentation of teaching materials (student assessment points number 7-18) a score of 4.15 means that the material developed is good. Assessment indicators include shape and size, ease of use, choice of color, use of letters, illustration images, content of material, usability of teaching materials, and quality of technique with respective scores.

With the results of obtaining such a score, the teaching material product is feasible in terms of student assessment by referring to the provision that teaching materials are declared eligible if the minimum score calculation is included in good criteria.

The results of observations made in the three stages of the field test showed that the application product developed in the trial stage seemed able to attract students' interest in learning. After the teaching materials were distributed to students, the students seemed enthusiastic about using the application product. Student interest in the world history baboon book application is a good symptom to improve student learning achievement. Initially, students felt less interested in world history 
material because it was considered boring and not contextual. The application developed here can act as an alternative source of student learning that is more interesting than just reading the grand narrative literature so that through this teaching material students have alternative learning resources besides the literature they usually use. Of the three stages of field trials, no revision process was carried out on the developed application product. During the field trials, no significant obstacles were found that required revisions. This is in line with the opinion of Giroux (2005: 426) that product revisions are carried out if there are deficiencies and weaknesses.

\subsection{Effectiveness Test}

After the big data-based baboon book application is used by lecturers in the American history learning process, the next step is to see how effective the product is through learning outcomes tests on 34 Regular C class history education students. The following are the results of student learning tests.

Table 4. Product Effectiveness Test Results

\begin{tabular}{ccc}
\hline Students & Score & Completeness \\
\hline 1 & 70 & complete \\
2 & 70 & complete \\
3 & 94 & complete \\
4 & 95 & complete \\
5 & 97 & complete \\
6 & 89 & complete \\
7 & 97 & complete \\
8 & 90 & complete \\
9 & 97 & complete \\
10 & 98 & complete \\
11 & 97 & complete \\
12 & 73 & complete \\
13 & 95 & complete \\
14 & 97 & complete \\
15 & 90 & complete \\
16 & 96 & complete \\
17 & 97 & complete \\
18 & 83 & complete \\
19 & 89 & complete \\
20 & 89 & complete \\
21 & 90 & complete \\
22 & 90 & complete \\
23 & 89 & complete \\
24 & 89 & complete \\
25 & 90 & complete \\
26 & 91 & complete \\
27 & 92 & complete \\
28 & 93 & complete \\
29 & 92 & complete \\
30 & 90 & complete \\
31 & 92 & complete \\
32 & 92 & complete \\
& &
\end{tabular}

\begin{tabular}{rrc}
33 & 93 & $\begin{array}{c}\text { complete } \\
\text { complete }\end{array}$ \\
34 & 90 & $\mathbf{9 0 . 4 7}$ \\
\hline \multicolumn{3}{c}{ Average }
\end{tabular}

Based on the table above, the average score of student learning outcomes is 90.47 with a total of 34 students completeness. The average score obtained by students who have been percentage indicates that the completeness of the learning outcomes test obtained by students is $100 \%$. This means that $100 \%$ of students have met the threshold value, so it can be concluded that this media is very effectively used in the learning process. (Kahn, 2008)

\section{CONCLUCION}

The development of the big data-based world history baboon book application can increase students' theoretical understanding and interest, especially in spatial history material. The results obtained indicate that based on the results of the material expert validation, the appropriate criteria were obtained with an average of 77.1, while the media expert validation obtained very feasible criteria with an average of 92.5. The last stage is the effectiveness test that can be obtained based on student learning outcomes tests, obtained an average of 90.47 which means that the big data-based baboon book application is effectively used in the spatial history learning process.

\section{REFERENCES}

[1] Borg, W. R. \& Gall, M. D. (2003). Educational research. New York: Allyn \& Bacon

[2] Giroux, H.A. (2005) What is Critical Pedagogy? Boston University

[3] Gooch, D. L. (2012). Reseacrh, Development, and Validation of a School Leader's Resource Guide for The Facilitation of Sosial Media Use by School Staff. Manhattan, Kansas: Kansas State University.

[4] Kahn, Richard (2008). From Education for Sustainable Development to Ecopedagogy: Sustaining Capitalism or Sustaining Life? dalam Green Theory \&bPraxis: The Journal of Ecopedagogy Volume 4, No 12008.

[5] Ponting, Clive. (2007). A New Green History of The World. Amazone: USA 